\title{
VIOLÊNCIA OBSTÉTRICA NO BRASIL: UM ENFOQUE A PARTIR DOS ACÓRDÃOS DO STF E STJ
}

\author{
Artenira da Silva e Silva ${ }^{1}$ \\ Maiane Cibele de Mesquita Serra ${ }^{2}$
}

\begin{abstract}
Resumo
Este trabalho objetiva analisar e discutir o fenômeno da violência obstétrica no Brasil a partir da análise dos acórdãos do Supremo Tribunal Federal (STF) e do Superior Tribunal de Justiça (STJ), propondo-se ainda, fazer uma reflexão sobre a forma de atuação do judiciário diante dos casos. Utiliza-se uma abordagem quanti-qualitativa e o procedimento metodológico de análise documental mediante a avaliação e análise de conteúdo dos acórdãos. Buscas exploratórias através de palavras-chave caracterizadoras da violência obstétrica foram realizadas nos sítios eletrônicos dos respectivos tribunais entre os anos de 2007 a 2016. Foram selecionados, analisados e discutidos os julgados que mais evidenciavam a temática abordada.
\end{abstract}

Palavras-chave: Violência obstétrica. Parturientes. Direitos. Mulheres.

\section{INTRODUÇÃO}

A violência é um problema social que está em constante processo de expansão em todas as suas formas. A violência contra a mulher, em especial, é um problema do Estado, uma vez que é uma das violações mais frequentes dos direitos humanos e constitui-se como um problema de saúde pública que gera custos econômicos e sociais elevados para qualquer país no qual haja elevada incidência do referido fenômeno. Tal modalidade de violência tem perdurado ao longo da história e na atualidade ganhou caráter endêmico, uma vez que está cotidianamente presente nas comunidades e países de todo o mundo, independentemente da classe social, raça, idade, sexo ou religião. (FONEITE; FEU; MERLO, 2012).

A Organização Mundial de Saúde (OMS) define violência como a imposição de um grau significativo de dor e sofrimento evitáveis. Por sua vez, a violência contra a mulher é definida pela Convenção Interamericana

\footnotetext{
${ }^{1}$ Pós-doutora em Psicologia e Educação pela Universidade do Porto. Docente e pesquisadora do Departamento de Saúde Pública e do Mestrado em Direito e Instituições do Sistema de Justiça da Universidade Federal do Maranhão. Coordenadora de linha de pesquisa do Observatório Ibero Americano de Saúde e Cidadania e coordenadora do Observatorium de Segurança Pública (PPGDIR/UFMA/CECGP).E-mail: artenirassilva@hotmail.com

${ }^{2}$ Mestranda em Direito e Instituições do Sistema de Justiça, do Programa de Pós-Graduação em Direito da Universidade Federal do Maranhão (PPGDIR/UFMA). Bolsista CAPES.E-mail: maianeserra@hotmail.com
} 
para Prevenir, Punir e Erradicar a Violência contra a Mulher, também conhecida como "Convenção de Belém do Pará", no seu art. $1^{\circ}$ como: "qualquer ato ou conduta baseada no gênero, que cause morte, dano ou sofrimento físico, sexual ou psicológico à mulher, tanto na esfera pública como na esfera privada”. E no art. 6o determina que o direito de toda mulher a ser livre de violência, abrange, entre outros, o direito a ser livre de todas as formas de discriminação, além do direito de ser valorizada e educada livre de padrões estereotipados de comportamento e costumes sociais e culturais baseados em conceitos de inferioridade ou subordinação.

No que tange à violência de gênero podemos considerar as violências física, sexual e psicológica ocorridas tanto no âmbito privado quanto público, podendo ser perpetradas inclusive pelo Estado e seus agentes. Tal tipo de violência manifesta-se por meio das relações de poder, histórica e culturalmente desiguais, ocorridas entre homens e mulheres.

Em muitas instituições de saúde, os direitos reprodutivos das mulheres são sistematicamente violados durante o parto e convertidos em formas naturalizadas de violência. Nesse sentido, a violência obstétrica, conhecida também como violência institucional na atenção obstétrica corresponde a uma forma específica da violência de gênero, uma vez que há utilização arbitrária do saber por parte de profissionais da saúde no controle dos corpos e da sexualidade das parturientes. Consiste em uma expressão que agrupa as formas de violência e danos originados no cuidado obstétrico profissional, enquadrando-se nesse conceito, todos os atos praticados no corpo da mulher e do neonato sem o devido consentimento ou informação prestada à paciente.

A violência perpetrada nos corpos femininos fere categorias universais de direitos humanos, infringindo uma série de prerrogativas asseguradas pelo Estado brasileiro, tais como: a dignidade da pessoa humana (art. $1^{\circ}$, III, CRFB/88) como fundamento do Estado Democrático de Direito; o direito à vida (art. 5o, CRFB/88), a igualdade (art. 5, I, CRFB/88) que a protege de todas as formas de discriminação; à saúde (art. 6º art. 196 $\mathrm{CRFB} / 88$ ); o princípio da legalidade (art. $5^{\circ}, \mathrm{II}, \mathrm{CRFB} / 88$ ) que assegura autonomia à mulher; e ainda a proteção à maternidade e à infância (Princípio da Beneficência - art. $6^{\circ}$; art. 203, I, CRFB/88).

Destarte, este estudo se justifica pela relevância social e jurídica da temática, uma vez que consoante a pesquisa nacional "Mulheres brasileiras e gênero nos espaços público e privado" (VENTURI; GODINHO, 2010) realizada pela Fundação Perseu Abramo, uma em cada quatro mulheres sofre violência obstétrica, constituindo-se pois, em um tipo de violência de alta incidência.

Objetivou-se, a partir deste estudo, refletir sobre os seguintes problemas: É possível vislumbrar o fenômeno da violência obstétrica nos tribunais superiores? Em caso positivo, como os tribunais superiores têm atuado frente às demandas pertinentes à violência obstétrica no Brasil?

A partir do problema levantado, realizou-se uma busca através de palavras-chave correlacionadas às práticas de violência obstétrica, nos sítios eletrônicos do Supremo Tribunal Federal (STF) e Superior Tribunal de 
Justiça (STJ), no intuito de selecionar todos os acórdãos que poderiam ser utilizados para observância da violência obstétrica entre os anos de $2007^{3}$ a 2016. Após análise de cada acórdão encontrado, foi desenvolvida uma planilha no Microsoft Excel a fim de organizar os dados encontrados e agrupá-los conforme a saturação de núcleos de sentido encontrados nos documentos analisados.

Para alcançar os objetivos propostos utilizou-se como procedimento metodológico a análise documental mediante a avaliação dos acórdãos, propondo-se um tratamento quanti-qualitativo dos dados, agrupados por similitude e relevância de seus conteúdos.

Diante da relevância social e jurídica do assunto, objetiva-se ainda, trazer conhecimento e propor reflexões à sociedade, em geral, em especial, aos agentes de saúde, aos agentes dos sistemas de justiça, e às parturientes em relação ao fenômeno em questão.

\section{O CONCEITO NORMATIVO DE VIOLÊNCIA OBSTÉtRICA E A SUA FENOMENOLOGIA}

A construção do conceito da violência obstétrica está diretamente relacionada à história do parto, e se fez presente, sobretudo, após a inserção da prática obstétrica na medicina em que o parto deixou de ser um episódio natural, compartilhado apenas no seio familiar, para se tornar uma espécie de evento no ambiente hospitalar, prática dominada pela medicina e institucionalizada nos hospitais. (WOLFF; WALDOW, 2008; OSAVA, 1997).

Também conhecida como violência institucional na atenção obstétrica, a violência obstétrica abrange momentos distintos, quais sejam, pré-natal, parto, pós-parto e situações de abortamento, podendo ser perpetrada de modo verbal, físico, psicológico ou até mesmo sexual, expressando-se ainda, de modo explícito ou velado. (KONDO et al, 2014).

Segundo D‘Oliveira, Diniz e Schraiber (2002 apud AGUIAR, 2010), esta violência é expressa pela negligência na assistência, discriminação social, violência verbal (tratamento grosseiro, ameaças, reprimendas, gritos, humilhação intencional) e violência física (incluindo não-utilização de medicação analgésica quando tecnicamente indicada), até o abuso sexual. Outras pesquisas também apontam, como uma forma específica ilustrativa deste tipo de violência, o uso inadequado de tecnologia, com intervenções e procedimentos muitas vezes desnecessários em face das evidências científicas do momento, resultando numa cascata de intervenções com potenciais riscos e sequelas. (DINIZ; CHACHAM, 2006; DINIZ, 2001 apudAGUIAR, 2010).

\footnotetext{
${ }^{3}$ Marco inicial utilizado tendo em vista que em 16 de março de 2007 foi promulgada a Lei Orgânica sobre o Direito das Mulheres a uma Vida Livre de Violência na Venezuela, primeiro país latino-americano a adotar o conceito normativo para a violência obstétrica.
} 
Para fins de análise dessa modalidade de violência, adotou-se o conceito proposto por Chauí, sob dois ângulos:

Em primeiro lugar, como conversão de uma diferença e de uma assimetria em uma relação hierárquica de desigualdade com fins de dominação, de exploração e de opressão. Isto é, a conversão dos diferentes em desiguais e a desigualdade em relação entre superior e inferior. Em segundo lugar, como a ação que trata um ser humano não como sujeito, mas como uma coisa. Esta se caracteriza pela inércia, pela passividade e pelo silêncio, de modo que, quando a atividade e a fala de outrem são impedidas ou anuladas, há violência. (CHAUÍ, 1985, p. 35, grifo nosso).

Tal perspectiva coaduna com a violência obstétrica, uma vez que esta corresponde a uma forma específica da violência de gênero, em que há utilização arbitrária do saber por parte de profissionais da saúde no controle dos corpos e da sexualidade das parturientes.

Violência de gênero pode ser conceituada como qualquer ato que resulta ou possa resultar em dano ou sofrimento físico, sexual ou psicológico à mulher, inclusive ameaças de tais atos, coerção ou privação arbitrária de liberdade em público ou na vida privada, assim como castigos, maus tratos, pornografia, agressão sexual e incesto. (KRONBAUER; MENEGHEL, 2014, p. 01).

Para Joan Scott "o gênero é um elemento constitutivo das relações sociais baseado nas diferenças percebidas entre os sexos" (1995, p. 86). Por outro lado é, também, "uma forma primária de dar significado às relações de poder" (1995, p. 86). Desta forma, tem-se nas diferenças de gênero, um lugar propício para o exercício do poder representado através de uma ideologia dominante com normas que expressam claramente os papéis sociais diferenciados para homens e mulheres.

Nesse sentido, para compreensão da violência obstétrica, faz-se necessário o entendimento de gênero como elemento constitutivo das relações sociais, baseado nas diferenças entre os sexos e como componente primordial das relações de poder.

O conceito de poder também é norteador para análise deste fenômeno, uma vez que a violência obstétrica se dá no seio das relações desiguais de poder, a saber, as relações de gênero e a relação profissional entre médico/paciente.

Segundo Foucault (1995) a profissão médica exerce um poder sem controle sobre os corpos das pessoas, sua saúde, vida e morte. Esse poder médico se baseia na autoridade cultural e moral que a profissão médica exerce em nossa sociedade. Para Foucault (1982), o discurso daquele que ordena a sociedade é sempre o discurso daquele que detém o saber. Desta forma,

Na posição de doutores de um saber, sobre um outro que é objeto, médicos destronam a posição terapêutica para ocupar um lugar que nos ensina como devemos viver. Aqui, constata-se de maneira inteligível, o quanto o saber médico se articula ao poder disciplinar e normalizador. A ordem médica, assim compreendida articulada à microfisica do saber e poder, com seu olhar focado na doença e não na pessoa do doente, implica uma recusa e desqualificação da subjetividade e singularidade de cada fato clínico. (TAVIRA, 2014, p. 1). 
Assim, o discurso médico é concebido como o discurso da verdade e seus profissionais aparecem como uma das autoridades mais importantes do nosso tempo. Isto tem consequências vitais, porque o discurso médico assume um poder institucional privilegiado, além da legitimação social para administrar e governar a vida.

Nas últimas décadas, o empoderamento feminino no evento do parto natural, sendo a parturiente a verdadeira protagonista na condução do processo de parir foi gradativamente sendo substituído pelas várias intervenções médicas, muitas vezes invasivas e desnecessárias, podendo transformar um momento único e especial em um traumático episódio de intenso potencial desestruturante quando caracterizada a violência obstétrica.

O conceito normativo da prática foi adotado pela Venezuela, primeiro país latino-americano a utilizar a expressão "violência obstétrica" na Lei Orgânica sobre o Direito das Mulheres a uma Vida Livre de Violência promulgada em 16 de março de 2007.

Posteriormente o termo "obstetric violence" foi cunhado no meio acadêmico pelo presidente da Sociedade de Obstetrícia e Ginecologia da Venezuela, Dr. Rogelio Pérez D’Gregorio em um editorial online publicado em 6 de outubro de 2010 no International Journal of Gynecology and Obstetrics, descrevendo as menções específicas da nomenclatura "violência obstétrica" ora citada na lei venezuelana.

Desde então, os movimentos feministas passaram a utilizar o termo na luta pela eliminação e punição dos atos e demais procedimentos violentos realizados durante o atendimento e assistência ao parto, em prol da humanização no momento da concepção.

No Brasil, Fernando Magalhães, considerado o "Pai da Obstetrícia Brasileira" começou a empregar o termo "humanizar" no início do século XX e o professor Jorge de Rezende, na segunda metade do século.

A humanização na assistência ao parto requer uma mudança na compreensão do parto como experiência humana de dor, propondo também uma mudança sobre "o que fazer" diante do sofrimento do outro.

Conforme a Defensoria Pública do Estado de São Paulo (2013), que utilizou os conceitos presentes nas leis da Venezuela e Argentina, a violência obstétrica caracteriza-se pela apropriação do corpo e processos reprodutivos das mulheres pelos profissionais de saúde, através do tratamento desumanizado, abuso de medicalização e patologização dos processos naturais, causando a perda da autonomia e capacidade de decidir livremente sobre seus corpos e sexualidade, impactando negativamente na qualidade de vida das mulheres.

Salienta-se que o termo às vezes pode repassar uma impressão equivocada de uma violência somente no que tange as violações de caráter físico contra a parturiente, malgrado a imposição de intervenções danosas envolvam tanto a integridade física como a sexual e psíquica da mulher, desrespeitando sua autonomia. Segundo a OMS (2014), muitas das intervenções que são aplicadas rotineiramente são consideradas como um fator de risco 
tanto para a mulher quanto para o neonato. Ademais, as crenças e os preconceitos no que concerne à sexualidade e saúde das mulheres em uma sociedade tipicamente patriarcal contribuem sobremaneira na forma como elas são percebidas e (des)tratadas pelos mais diversos profissionais que sobre elas podem exercer algum poder em seus exercícios funcionais.

Ademais, a violência obstétrica é fortemente condicionada por preconceitos de gênero. Consoante Aguiar:

Estes maus tratos vividos pelas pacientes, na maioria das vezes, segundo alguns autores, encontram-se relacionados a práticas discriminatórias por parte dos profissionais, quanto a gênero, entrelaçados com discriminação de classe social e etnia, subjacentes à permanência de uma ideologia que naturaliza a condição social de reprodutora da mulher como seu destino biológico, e marca uma inferioridade física e moral da mulher que permite que seu corpo e sua sexualidade sejam objetos de controle da sociedade através da prática médica. (2010, p. 15).

No segundo semestre de 2014, a OMS se pronunciou a respeito da temática, publicando em seis idiomas uma declaração acerca da violência obstétrica, exigindo políticas e promoção à assistência obstétrica humanizada, além da adoção de medidas governamentais no sentido de abolir o desrespeito e abuso contra as mulheres durante o parto. Segundo a Organização:

Todas as mulheres têm direito ao mais alto padrão de saúde atingível, incluindo o direito a uma assistência digna e respeitosa durante toda a gravidez e o parto, assim como o direito de estar livre da violência e discriminação. Os abusos, os maus-tratos, a negligência e o desrespeito durante o parto equivalem a uma violação dos direitos humanos fundamentais das mulheres, como descrevem as normas e princípios de direitos humanos adotados internacionalmente. Em especial, as mulheres grávidas têm o direito de serem iguais em dignidade, de serem livres para procurar, receber e dar informações, de não sofrerem discriminações e de usufruírem do mais alto padrão de saúde física e mental, incluindo a saúde sexual e reprodutiva. (2014, p. 1-2).

O sistema jurídico brasileiro não possui legislação específica sobre a temática "violência obstétrica", apenas abordagem genérica. A lei brasileira 11.340/06 de combate a violência contra a mulher (Lei Maria da Penha) limita-se ao âmbito doméstico e familiar, de modo distinto dos outros países da América Latina cujas legislações específicas versam sobre diversas modalidades de violência cometidas contra as mulheres por sua condição de gênero.

Desde 2014, tramita no Brasil, o Projeto de Lei 7.633/2014, que dispõe sobre a humanização da assistência à mulher e ao neonato durante o ciclo gravídico-puerperal e dá outras providências, entre elas a condenação civil e criminal dos profissionais de saúde que pratiquem atos de violência obstétrica, notificando-se ainda, os Conselhos Regionais de Medicina e de Enfermagem, para os devidos encaminhamentos e aplicações de penalidades administrativas aos profissionais envolvidos, conforme expresso no art. 17 , $\$ \$ S 1^{\circ} \mathrm{e} 2^{\circ}$ do respectivo projeto. A situação atual do projeto é “aguardando parecer do Relator na Comissão de Educação (CE)".

${ }^{4}$ Jornal internacional de Ginecologia e Obstetrícia. 
Elaborado pela $\operatorname{Artemis}^{5}$ que atua na defesa e promoção dos direitos das mulheres e assinado pelo deputado Jean Wyllys - PSOL/RJ, o projeto é um instrumento normativo amplo, que não se limita ao parto humanizado, mas expressa, de modo claro, todas as condutas mais comuns que podem configurar a violência obstétrica (art. 14), propondo ainda medidas que visam a erradicação do problema e outras no que tange ao controle dos índices de cirurgias cesarianas, recomendando ainda boas práticas obstétricas.

Considerando-se a realidade brasileira, alguns estados instituíram leis que tipificam a violência obstétrica. Através de um breve levantamento, constatam-se as legislações de Diadema (SP) e Curitiba (PR), Lei no 3.363/13 e Lei no 14.598/15, respectivamente. Em dezembro de 2016, foi aprovado também em Santa Catarina o Projeto de Lei 0482.9/2013 que versa sobre a temática. O projeto de lei federal e as legislações municipais possuem características semelhantes expondo os casos mais recorrentes da prática.

O Brasil possui ainda a Lei 11.108/2005 que garante às parturientes o direito à presença de acompanhante durante o trabalho de parto, parto e pós-parto imediato, no âmbito do Sistema Único de Saúde SUS, direito que se negado, configura como uma das práticas de violência obstétrica. Entretanto, a lei é muito genérica e apenas menciona o direito de um acompanhante à escolha da parturiente.

A violência obstétrica frequentemente culmina em danos físicos, psicológicos e sexuais em forma de violência institucional contra mulheres.

Durante a gestação a violência obstétrica pode ser caracterizada por: negar atendimento à mulher ou ainda impor a ela alguma dificuldade ao atendimento em postos de saúde onde são realizados o acompanhamento pré-natal. Ainda constituem formas de violência obstétrica as seguintes práticas: qualquer espécie de comentários constrangedores à mulher relacionados à sua cor, raça, etnia, idade, escolaridade, religião ou crença, condição econômica, estado civil ou situação conjugal, orientação sexual, número de filhos, etc; ofender, humilhar ou xingar a mulher ou sua família; negligenciar atendimento de qualidade; agendar cesárea sem recomendação baseada em evidências científicas, atendendo simplesmente aos interesses e conveniência do médico. (DEFESORIA PÚBLICA DO ESTADO DE SÃO PAULO, 2013).

Durante o parto, as formas mais comuns deste tipo de violência são: a recusa de admissão em hospital ou maternidade, gerando a chamada peregrinação por leito; impedimento da entrada do acompanhante escolhido pela mulher para acompanha-la durante o parto; aplicação de soro com ocitocina para acelerar o trabalho de parto; episiotomia de rotina ${ }^{6}$; manobra de Kristeller $^{7}$; cesáreas eletivas ${ }^{8}$; restrição da posição do parto; violência

\footnotetext{
${ }^{5}$ Entidade de referência na implantação de políticas e serviços voltados para a melhoria da vida das mulheres, dando suporte ao setor público e privado na execução das mesmas.

${ }^{6}$ Procedimento cirúrgico para aumentar a abertura do canal vaginal, cortando a entrada da vagina com uma tesoura ou bisturi, algumas vezes sem anestesia.
} 
psicológica; impedir ou retardar o contato do bebê com a mulher logo após o trabalho de parto; impedir o alojamento conjunto da mãe e o neonato; impedir ou dificultar o aleitamento materno; além de outros procedimentos dolorosos, desnecessários e humilhantes, tais como: uso rotineiro de lavagem intestinal (enema), retirada dos pelos pubianos (tricotomia), posição ginecológica com portas abertas, exames de toque sucessivos e por pessoas diferentes para verificar a dilatação, privação de alimentos e água, imobilização de braços e pernas, etc.

Nos casos de abortamento, a violência caracteriza-se por: negativa ou demora no atendimento à mulher em situação de abortamento; questionamento à mulher quanto à causa do abortamento (se foi intencional ou não); realização de procedimentos predominantemente invasivos, sem explicação, consentimento e frequentemente sem anestesia; ameaças, acusação e culpabilização da mulher; coação com finalidade de confissão e denúncia. (DEFESORIA PÚBLICA DO ESTADO DE SÃO PAULO, 2013).

Os casos de violência obstétrica possuem ainda um agravante vislumbrado a partir da hipossuficiência técnica dos julgadores no sentido de definir e caracterizar a problemática. Tal perspectiva pode ser observada nos acórdãos analisados no presente estudo que refletem a forma como sistema judiciário está estruturado e tem funcionado, revelando sua imprestabilidade diante das prementes necessidades coletivas da contemporaneidade.

A resolução em larga escala de conflitos individuais, generalizando decisões, sem que se avalie as peculiaridades de cada caso, com a colagem de ementários de jurisprudência, modelos de peças e decisões sem qualquer reflexão crítica, reflete o desconhecimento da violência obstétrica como violação dos direitos humanos das parturientes, contribuindo, por conseguinte, para que esta seja encarada simplesmente como erro médico e não como violência de gênero, contribuindo para que fenômeno permaneça silente e, consequentemente, invisibilizado.

\section{VIOLENCIA OBSTÉTRICA NO BRASIL: UM ENFOQUE A PARTIR DOS ACÓRDÃOS DO STF E STJ}

O estudo em tela objetiva analisar a temática da violência obstétrica no Brasil a partir da análise dos acórdãos do Supremo Tribunal Federal e Superior Tribunal de Justiça. Optou-se como campo de estudo a ser considerado os sítios eletrônicos do STF e STJ, tendo em vista o impacto das decisões, a relevância institucional dos tribunais, bem como o papel dos mesmos na proteção dos direitos fundamentais.

A presente pesquisa tem abordagem quanti-qualitativa pressupondo uma análise dialética dos dados encontrados que permita enxergar ambas abordagens conjuntamente, trazendo elementos que se complementam

\footnotetext{
${ }^{7}$ Manobra na parte superior do útero, durante as contrações do parto, visando empurrar o nascituro em direção à pelve a fim de acelerar o trabalho de parto.
} 
e corroborando para uma interpretação mais abrangente da realidade posta.

Utilizou-se como procedimento metodológico a análise documental mediante a avaliação dos acórdãos do STF e STJ, envolvendo a temática. Conforme Silva e Grigolo:

A pesquisa documental vale-se de materiais que ainda não receberam nenhuma análise aprofundada. Esse tipo de pesquisa visa, assim, selecionar, tratar e interpretar a informação bruta, buscando extrair dela algum sentido e introduzir-lhe algum valor, podendo, desse modo, contribuir com a comunidade científica a fim de que outros possam voltar a desempenhar futuramente o mesmo papel. (apudBEUREN, 2006, p. 89).

Inicialmente foi realizada uma busca jurisprudencial exploratória nos sítios eletrônicos dos respectivos tribunais de todos os acórdãos entre os anos de 2007 até o ano de 2016, utilizando-se inicialmente como palavrachave "violência obstétrica", sem, no entanto, encontrar nenhum resultado. Posteriormente, foram utilizadas outras palavras caracterizadoras a fim de se chegar aos resultados desejados: episiotomia, manobra de Kristeller, lesão no parto, erro médico no parto, fórceps, parto demorado, parto, perda do útero e ocitocina.

Após a coleta desses dados, cada acordão foi detalhadamente analisado a fim de averiguar se de fato havia alguma situação caracterizadora da violência obstétrica nos casos em estudo. A partir desta primeira análise, intencionou-se verificar se a temática da violência obstétrica tem alcançando os tribunais superiores do Brasil e como estes tem atuado na defesa dos direitos das parturientes vítimas dessa prática.

Para avaliação dos acórdãos coesos com o objeto de estudo pesquisado criou-se critérios de exclusão, sendo suprimidos os acórdãos relacionados a negativa por parte do plano de saúde no momento do parto; questões trabalhistas ligadas à maternidade; prorrogação de testes físicos em concursos públicos quando a Requerente encontrava-se grávida, além de outros acórdãos que não possuíam liame com danos tipificados nas condutas de violência obstétrica.

A realização da análise pormenorizada dos acórdãos se deu ainda a partir do preenchimento de uma tabela no Microsoft Excel, sendo especificadas as seguintes variáveis: órgão julgador; número do processo; data da publicação; polo ativo; polo passivo; instrumento processual utilizado; relator; órgão julgador (turma); palavra caracterizadora; forma de atendimento (hospital público ou privado); violência sofrida (mulher e bebê); dano mencionado no acórdão; causa do dano; sanção estabelecida no acórdão; decisão favorável ou desfavorável.

\section{Resultados e discussões}

O estudo é composto por 35 acórdãos, sendo 3 na esfera do STF e 32 na esfera no STJ. Para fins de enquadramento da conduta tipificada nos acórdãos como violência obstétrica considera-se os danos perpetrados tanto pelos agentes de saúde no desempenho de atividade médico-hospitalar, quanto pelo estabelecimento de

\footnotetext{
${ }^{8}$ Cesárea realizada sem fatores de risco que justifiquem o procedimento, e antes da criança emitir qualquer sinal de que está pronta.
} 
saúde, contra parturientes e neonatos.

A fim de ter uma amostragem mais precisa acerca dos danos iatrogênicos vislumbrados em cada julgado, bem como seu quantitativo, desenvolveu-se uma tabela com especificando o órgão, número do processo e as situações violadoras, conforme exposto abaixo:

Tabela 1: Órgão, número dos processos analisados e danos iatrogênicos

\begin{tabular}{|c|c|c|}
\hline ORGÃO & NUMÉRO DO PROCESSO & DANOS IATROGÊNICOS \\
\hline STF & $\begin{array}{l}\text { AG.REG. NO RECURSO EXTR. COM } \\
\text { AGRAVO } 733.844 \text { - RJ }\end{array}$ & Demora no parto - sequelas no neonato \\
\hline STF & $\begin{array}{l}\text { AG.REG. NO AGRAVO DE } \\
\text { INSTRUMENTO 852.237 - RS }\end{array}$ & Episiotomia - lesão esfincteriana grave \\
\hline STF & $\begin{array}{l}\text { AG.REG. NO RECURSO } \\
\text { EXTRAORDINÁRIO } 600.866 \text { - RJ }\end{array}$ & $\begin{array}{l}\text { Recusa no atendimento - demora no parto - sequelas no } \\
\text { neonato }\end{array}$ \\
\hline STJ & $\begin{array}{l}\text { AgRg no AGRAVO EM RECURSO } \\
\text { ESPECIAL 442.266 - SP }\end{array}$ & $\begin{array}{l}\text { Aplicação de ocitocina combinada com misoprostol - } \\
\text { choque anafilático na parturiente - sequelas neonato }\end{array}$ \\
\hline STJ & $\begin{array}{l}\text { EDcl nos EDcl no AGRAVO EM } \\
\text { RECURSO ESPECIAL 706.352 - MG }\end{array}$ & $\begin{array}{l}\text { Demora no atendimento - uso de fórceps - } \\
\text { sequelas no neonato }\end{array}$ \\
\hline STJ & RECURSO ESPECIAL 1.595.761 - SC & Demora no parto - cesárea tardia - feto retirado sem vida \\
\hline STJ & $\begin{array}{l}\text { AgRg no AGRAVO EM RECURSO } \\
\text { ESPECIAL } 147.484 \text { - RJ }\end{array}$ & Demora no parto - morte do neonato \\
\hline STJ & RECURSO ESPECIAL 1.245.063 - RJ & Demora no parto - morte do neonato \\
\hline STJ & $\begin{array}{l}\text { AgRg no AGRAVO EM RECURSO } \\
\text { ESPECIAL } 427.100 \text { - BA }\end{array}$ & Demora no parto - sequelas no neonato \\
\hline STJ & $\begin{array}{c}\text { AgRg no AGRAVO EM RECURSO } \\
\text { ESPECIAL } 69.698 \text { - RN }\end{array}$ & Demora no parto - sequelas no neonato \\
\hline STJ & RECURSO ESPECIAL 1.548 .847 - SP & Demora no parto - sequelas no neonato \\
\hline STJ & $\begin{array}{l}\text { AgRg no AGRAVO EM RECURSO } \\
\text { ESPECIAL } 403.761 \text { - SC }\end{array}$ & Demora no parto - sequelas no neonato \\
\hline STJ & $\begin{array}{l}\text { AgRg no AGRAVO EM RECURSO } \\
\text { ESPECIAL 241.652 - RJ }\end{array}$ & Demora no parto - sequelas no neonato \\
\hline STJ & $\begin{array}{l}\text { AgRg no AGRAVO EM RECURSO } \\
\text { ESPECIAL 137.102 - PB }\end{array}$ & Demora no parto - sequelas no neonato \\
\hline STJ & $\begin{array}{l}\text { AgRg no AGRAVO EM RECURSO } \\
\text { ESPECIAL 746.902 - SC }\end{array}$ & Demora no parto - sequelas no neonato \\
\hline STJ & $\begin{array}{c}\text { AgRg no AGRAVO EM RECURSO } \\
\text { ESPECIAL 190.929- SP }\end{array}$ & Demora no parto - sequelas no neonato \\
\hline STJ & $\begin{array}{c}\text { AgRg no AGRAVO EM RECURSO } \\
\text { ESPECIAL 634.241 - SP }\end{array}$ & Demora no parto - sequelas no neonato \\
\hline STJ & RECURSO ESPECIAL 1.195.656 - BA & $\begin{array}{c}\text { Demora no parto - sequelas no neonato - tratamento } \\
\text { desumano à parturiente }\end{array}$ \\
\hline STJ & RECURSO ESPECIAL 1.351.105 - SP & Desaparecimento do natimorto do nosocômio \\
\hline STJ & RECURSO ESPECIAL 740.574 - SP & Erro médico - curetagem - esterilidade \\
\hline
\end{tabular}

podendo ser agendada e feita conforme a conveniência médica. 


\begin{tabular}{|c|c|c|}
\hline STJ & RECURSO ESPECIAL 1.386 .389 - RJ & $\begin{array}{c}\text { Erro médico - curto circuito em bisturi elétrico provocando } \\
\text { queimaduras na parturiente - abalo psicológico }\end{array}$ \\
\hline STJ & RECURSO ESPECIAL 1.174 .490 - MA & $\begin{array}{l}\text { Erro médico - esquecimento de compressa cirúrgica - } \\
\text { septicemia (infecção generalizada) e perda parcial do útero }\end{array}$ \\
\hline STJ & $\begin{array}{l}\text { AgRg no AGRAVO EM RECURSO } \\
\text { ESPECIAL 209.743 - RJ }\end{array}$ & $\begin{array}{l}\text { Erro médico - lesão traumática causada no momento do } \\
\text { parto natural (fístula retovaginal) }\end{array}$ \\
\hline STJ & $\begin{array}{l}\text { AgRg no AGRAVO EM RECURSO } \\
\text { ESPECIAL } 144.794 \text { - RJ }\end{array}$ & Erro médico - morte do neonato - perda do útero \\
\hline STJ & $\begin{array}{l}\text { AgRg no AGRAVO EM RECURSO } \\
\text { ESPECIAL } 180.480 \text { - SP }\end{array}$ & $\begin{array}{l}\text { Erro médico - morte do neonato - substância para induzir } \\
\text { parto - parturiente sem acompanhamento médico }\end{array}$ \\
\hline STJ & $\begin{array}{l}\text { AgRg nos EDcl no AGRAVO DE } \\
\text { INSTRUMENTO 854.005 - MT }\end{array}$ & $\begin{array}{l}\text { Erro médico - prescrição de medicamento irregular - morte } \\
\text { do nascituro - perda do útero }\end{array}$ \\
\hline STJ & $\begin{array}{l}\text { AgRg no AGRAVO EM RECURSO } \\
\text { ESPECIAL 221.113 - RJ }\end{array}$ & $\begin{array}{c}\text { Erro médico - sequelas no neonato - indicação de cesariana } \\
\text { não observada }\end{array}$ \\
\hline STJ & RECURSO ESPECIAL 1.526 .467 - RJ & $\begin{array}{c}\text { Erro médico - sequelas no recém-nascido - indicação de } \\
\text { cesariana não observada - demora no atendimento - uso de } \\
\text { fórceps }\end{array}$ \\
\hline STJ & $\begin{array}{c}\text { AgRg no AGRAVO EM RECURSO } \\
\text { ESPECIAL 221.110 - RJ }\end{array}$ & $\begin{array}{l}\text { Erro médico - sequelas no recém-nascido - indicação de } \\
\text { cesariana não observada }\end{array}$ \\
\hline STJ & $\begin{array}{l}\text { AgRg no AGRAVO EM RECURSO } \\
\text { ESPECIAL 645.884 - SC }\end{array}$ & $\begin{array}{l}\text { Erro médico no parto - lesão permanente na criança } \\
\text { causando atrofia (restrição funcional) }\end{array}$ \\
\hline STJ & $\begin{array}{l}\text { AgRg no AgRg no AGRAVO EM } \\
\text { RECURSO ESPECIAL 672.584 - DF }\end{array}$ & Manobra de Kristeller - sequelas no neonato \\
\hline STJ & $\begin{array}{l}\text { AgRg no AGRAVO EM RECURSO } \\
\text { ESPECIAL } 628.542 \text { - RJ }\end{array}$ & $\begin{array}{c}\text { Manobra de Kristeller - uso de fórceps - sequelas no } \\
\text { neonato }\end{array}$ \\
\hline STJ & RECURSO ESPECIAL No 1.024 .693 - SP & $\begin{array}{l}\text { Negligência e imprudência médica antes e após o parto - } \\
\text { lesões no neonato }\end{array}$ \\
\hline STJ & RECURSO ESPECIAL 1.173.058 - DF & $\begin{array}{l}\text { Omissão de socorro e imperícia na realização do parto - } \\
\text { demora no parto - sequelas no neonato }\end{array}$ \\
\hline STJ & $\begin{array}{l}\text { AgRg no AGRAVO EM RECURSO } \\
\text { ESPECIAL 61.034 - RJ }\end{array}$ & $\begin{array}{l}\text { Teste de HIV realizado em gestante em trabalho de parto - } \\
\text { falso resultado positivo }\end{array}$ \\
\hline
\end{tabular}

Percebe-se que a maioria dos acórdãos analisados são originários das regiões Sul e Sudeste do Brasil, localidades que consequentemente desenvolvem mais políticas relacionadas ao combate à violência obstétrica do que as outras regiões do país.

Os casos, aos poucos, têm alcançando a esfera dos supremos tribunais, sem entretanto, evidenciar a devida notoriedade e intensidade de dano quanto à problemática da violência obstétrica, fator não exposto nos acórdãos mesmo sendo notória a violação dos direitos das parturientes, conforme vislumbra-se nos danos iatrogênicos observados.

Além disso, depreende-se também a partir da análise dos acórdãos que a maior parte das violações ocorre 
na rede pública de saúde em comparação com a rede privada?

Conforme Diniz e Chacham (2006) somente 30\% das mulheres possuem algum tipo de seguro-saúde privado e as 70\% mais pobres dependem do Sistema Único de Saúde (SUS). Além disso, os dados colhidos a partir da pesquisa nacional "Mulheres brasileiras e gênero nos espaços público e privado" (VENTURI; GODINHO, 2010) ratificam as impressões obtidas a partir dos acórdãos analisados no que tange as formas de atendimento prestado a estas mulheres, uma vez que conforme percentual coletado na pesquisa, $74 \%$ das mulheres sofreram algum tipo de violência no atendimento ao parto na rede pública, em detrimento de 17\% na rede privada e $8 \%$ em ambas instituições, em uma amostragem de 2.365 mulheres entrevistadas.

Destaca-se ainda que o fato de dependerem dos serviços públicos de saúde por serem hipossuficientes economicamente é considerado por algumas mulheres como um estigma social, sendo um fator predisponente à anulação de sua cidadania no que diz respeito à falta de acesso aos serviços de saúde. (RODRIGUES et al, 2015).

O fenômeno da violência obstétrica ainda é invisibilizado do ponto de vista jurídico, não sendo uma temática recorrente no judiciário brasileiro. Todavia, muito embora o termo não apareça nos julgados analisados, as buscas exploratórias através de palavras-chave caracterizadoras e posterior análise dos acórdãos selecionados expressam categoricamente a violação dos direitos humanos das parturientes.

\section{Demora no atendimento ao parto}

Depreende-se da análise, um número significativo de lesões às parturientes e neonatos decorrentes da demora para realização do parto, sendo associado a negativa de atendimento por parte dos profissionais de saúde, médico indisponível ou ainda indisponibilidade de vaga, leito obstétrico ou UTI neonatal, gerando a chamada peregrinação por leito, ocasionando um grave problema de saúde pública na rede de atenção à saúde materna. Nesse sentido,

[...] a carência de vagas na assistência obstétrica, a peregrinação e o não atendimento de suas necessidades, ressalta essa insatisfação além de aumentar a vulnerabilidade dessas mulheres e de seus filhos. Portanto, é possível constatar a violência obstétrica na medida em que o direito constitucional e institucional não lhes foi garantido [...] a peregrinação na assistência obstétrica transforma um ideário de acessibilidade em violência institucional, uma vez que a condição de cidadania é desrespeitada como garantia legal [...] A falta de cuidado, o desrespeito e a recusa de atendimento podem ser observados no cotidiano da prática de alguns profissionais de saúde, constituindo-se uma realidade da assistência obstétrica nos serviços de saúde, configurando uma violência de caráter institucional ocasionada pela falta de apoio no cuidado à mulher, como o acolhimento, observado no (des) cuidado com ela frente ao processo de peregrinação. [...] A violência institucional vivenciada durante a peregrinação perpassa pela omissão de cuidados maternos, agravada por insultos, humilhações, ofensas, desrespeito, discriminação e culpabilização, que ocorrem por conta dessa relação de desigualdade, caracterizando um tipo de violência injustificada.

\footnotetext{
${ }^{9}$ Dos 35 acórdãos analisados, 25 são referentes a processos envolvendo a rede pública de saúde e 10 envolvendo a rede privada.
} 
(RODRIGUES et al, 2015, p. 617-618).

Diante do relevante número de acórdãos abordando a temática, escolheu-se os mais expressivos pela gravidade dos danos causados, bem como pela maior frequência dos danos referidos, a fim de demonstrar a atuação profissional iatrogênica provocada pela demora e/ou recusa no atendimento das parturientes. O acórdão recorrido abaixo assentou que:

[...] Pelo que se depreende dos autos, houve demora no atendimento, provavelmente por ter a médica realizado diversos partos naquela data, havendo a informação de que teria tentado fazer com que a paciente retornasse à sua residência, suspendendo a internação, pois não iria fazer mais partos naquela data, somente reconsiderando após a intervenção da enfermeira que Ihe informou estar a paciente já em trabalho de parto. [... ] Tal alegação consta na inicial e não foi afastada pelo Município. Por lado, verifica-se pelo laudo pericial que a cesariana era necessária e que a fratura da perna ocorreu pela ação da médica, não sendo essa consequência natural do parto cesáreo. (STF, AG.REG. NO RECURSO EXTRAORDINÁRIO 600.866 - RJ, Relator: Min. Gilmar Mendes, Segunda Turma, Data de Julgamento: 27 de novembro 2012, Data da Publicação: 13 de dezembro de 2012, p. 3, grifo nosso).

O tratamento desrespeitoso demonstrado por uma conduta antiética em negar atendimento à parturiente, contraria os princípios adotados pela Política de Humanização da Assistência e constitui-se como agressão aos direitos sexuais, reprodutivos e humanos, caracterizando como violência obstétrica de cunho psicológico, tendo em vista a instabilidade emocional provocada na mulher em um momento no qual ela se encontra particularmente vulnerável. (RODRIGUES et al, 2015).

Em outro caso relacionado a recusa por falta de vaga, encaminhamento a outra maternidade e consequentemente demora no atendimento, a parturiente dirigiu-se ao hospital por volta das 04:00h, entretanto, por falta de vaga foi encaminhada a um segundo hospital, já com perda de líquido amniótico há aproximadamente 7 horas, vindo a criança a nascer somente às $22 \mathrm{~h}$ com danos cerebrais permanentes e irreversíveis em razão do trabalho de parto prolongado, conforme se depreende do acórdão abaixo:

Ao que se verifica da farta documentação acostada, a parturiente por volta das 04:00 horas da manhã de 22/08/2009, sentiu fortes dores e contrações indicativas de trabalho de parto; dirigiu-se ao Hospital Stela Maris, mas, por falta de vaga para internação foi encaminhada ao Hospital Geral de Guarulhos. Ali, procedeu-se a internação às 10h00; foram realizados alguns exames rotineiros e administrado medicamentos presumidamente para indução; a ficha clínica de fi. 68 indica a perda de líquido há mais ou menos 7 horas; a criança nasceu às 22h00, nono mês de gestação, pesando $3.350 \mathrm{~kg}$, medindo $50 \mathrm{~cm}$, Apgar 2 e 4 e com afundamento no lado direito do crânio; constatada cianose e anoxia grave, foi reanimado ainda na sala do parto e encaminhado diretamente para a UTI neonatal, com traumatismo craniano, onde permaneceu por aproximadamente 04 (quatro) meses, além de outras internações sucessivas. Utiliza-se de sonda gástrica para se alimentar, em razão da incapacidade de sugar e deglutir (gastrostomia). Aparentemente, sofreu danos cerebrais permanentes e irreversíveis. Lamentável o estado da criança em razão das sequelas deixadas pelo mal que the acometeu durante o seu nascimento pelo suposto prolongamento do trabalho de parto (fl. 78) - e, segundo a narrativa, havia a presença de mecônio no líquido amniótico - e por falta, quiçá, de experiência ou habilidade dos profissionais ao se utilizarem dos afastadores Kieland e Simnpson para a retirada da criança do ventre materno. [...] 
Omisso o prontuário médico, que, até aqui só acusa anormalidades. Se, em tempo hábil, já que, não observada tal, circunstância para a realização do parto, tem-se por imperativo que o início de tratamento específico e imediato evitaria eventual agravamento das consequências sofridas. (AgRg no AGRAVO EM RECURSO ESPECIAL No 190.929 - SP, Relator: Min. Raul Araújo, Quarta Turma, Data de Julgamento: 24 de fevereiro de 2015, Data da Publicação: 20 de março de 2015, p. 4-5, grifo nosso).

A insegurança produzida pela incerteza de ter ou não uma vaga para realização do parto, associada à possibilidade de ter que por meios próprios peregrinar em busca da mesma é uma condição desumana, tendo as mulheres que retardar ao máximo a ida à maternidade para tentarem evitar o risco de serem transferidas, gerando riscos pare elas e para os bebês. (DIAS; DESLANDES, 2006).

Conforme Dias e Chacham:

As mulheres que usam o SUS durante o pré-natal frequentemente não conseguem reservar um lugar para o parto. As normas para o atendimento pré-natal recomendam que os profissionais de saúde forneçam à mulher no final da gravidez uma carta de recomendação a um hospital, para ajudá-las a conseguir um leito para o parto. Os profissionais de saúde referem-se jocosamente a esta carta como um "alvará de vire-se", pois em geral não produz resultado [...] Para mulheres que dependem do SUS, o acesso a um leito em qualquer maternidade apresenta vários problemas. Um deles é quando se dirigir ao hospital para assegurar acesso a um leito. Por não haver consenso sobre quando o trabalho de parto começa, alguns hospitais aceitam a mulher logo no início do processo, o que tende a produzir mais intervenções. Outros só aceitam as mulheres que estão prestes a dar à luz, o que dá a elas pouquíssimo tempo para procurar um leito (2006, p. 82).

Essa violação contraria inclusive o disposto na Lei 11.634 de 2007 que dispõe sobre o direito da gestante ao conhecimento e a vinculação à maternidade onde receberá assistência no âmbito do Sistema Único de Saúde, assegurando-lhe o direito ao conhecimento e à vinculação prévia a uma maternidade na qual será realizado seu parto ou ainda atendimento nos casos de intercorrência pré-natal, sendo consideradas barreiras no que tange aos direitos das parturientes na atenção humanizada ao parto.

Conforme Ventura (2009), as mulheres negras, indígenas e imigrantes possuem maiores dificuldades e preconceitos no que tange ao acesso à saúde, sendo mais vulneráveis à violência institucional, visto que representa uma violação de normas éticas e legais de direitos humanos.

Esse último julgado analisado no que tange a demora no parto mostra-se extremamente relevante para a configuração da violência obstétrica, uma vez que a partir da análise do inteiro teor do acórdão, constatamos que a parturiente sofreu suposto erro médico que ensejou o retardamento do parto causando-lhe lesões corporais, bem como submetendo a filha recém-nascida a "encefalopatia hipóxica isquêmica" ${ }^{10}$, ante a prolongada privação de oxigênio, causando-lhe gravíssima lesão cerebral, tida por irreversível, fazendo com que a menor dependa de

\footnotetext{
${ }^{10}$ Conforme a pediatra Dra. Maria Francielze Holanda Lavor, a encefalopatia hipóxica isquêmica consiste em uma síndrome neurológica, usualmente relacionada à asfixia perinatal que pode desencadear a cascata de alterações que culmina na lesão do sistema nervoso central. Ocorre em recém-nascido (RN) a termo ou pré-termo tardio ( $\geq 36$ semanas) e caracteriza - se por desconforto respiratório, apneia, alteração do nível de consciência, depressão dos reflexos e do tônus muscular e presença de convulsões.
} 
cuidados médicos especializados por toda a vida.

RECURSO ESPECIAL - AÇÃO DE INDENIZAÇÃO - DANOS MORAIS E MATERIAIS - ERRO MÉDICO - MÁ PRESTAÇÃO DE SERVIÇOS HOSPITALARES RETARDAMENTO DE PARTO E COMPROMETIMENTO DA SAÚDE DA MÃE E DA MENOR RECÉM-NASCIDA [...] ATENDIMENTO DESUMANO RECEBIDO PELA MÃE. COMPROMETIMENTO DE OXIGENAÇÃO NO CÉREBRO DA CRIANÇA. NASCIMENTO COM ENCEFALOPATIA DECORRENTE DE PERIOODO EXPULSIVO PROLONGADO. RESPONSABILIDADE DO MÉDICO. IMPERÍCIA E NEGLIGÊNCIA. HOSPITAL: RESPONSABILIDADE SOLIDÁRIA. CÓDIGO DO CONSUMIDOR. DANO MORAL. OCORRÊNCIA. VALOR. CRITÉRIOS: PENSÃO VITALÍCIA. É de causar estupefação e incredulidade eventos que narrados pela parturiente parecem ocorridos na idade média e não numa casa de saúde em pleno século XXI. Chegar num hospital às quatro horas da manhã sentindo dores de parto e somente ser o atendimento realizado à uma e meia da madrugada do dia seguinte; ou ainda permanecer com dores agonizantes durante todo esse tempo e ter que suplicar a presença de um médico para assistência sem conseguir; ou ficar depois do parto com forte mau cheiro em regióes intimas e desta forma ser mandada para casa; ou ser submetida a indiscriminados exames de toques, inclusive em pé, sendo alvo de ironia; ou ter efetuada tricotomia em partes intimas de forma agressiva e aviltante; ou ver realizado parto a destempo, apesar dos clamores, gerando como consequência o nascimento de filha com lesão cerebral permanente impeditiva de uma vida normal à genitora e ao rebento, tudo isso são alegaçôes que acaso comprovadas revelam o total descompromisso com a vida humana por quem a perpetrou, nada deixando a dever aos praticantes de torpes crimes que se encontram encarcerados em penitenciárias. (RECURSO ESPECIAL No 1.195.656 - BA (2010/0094662-0). Relator: Min. Massami Uyeda, Terceira Turma, Data de julgamento: 16 de agosto de 2011, Data da publicação: 30 de agosto de 2011, p. 5, grifo nosso).

Podemos analisar no caso em tela, mais de uma situação caracterizadora da violência obstétrica: demora demasiada no atendimento da parturiente; descaso; excessivos exames de toque; violência psicológica mediante ironia e humilhações; tricotomia agressiva e aviltante, culminando na lesão cerebral da recém-nascida, além dos danos psicológicos na parturiente.

Infelizmente, tais violações, arraigadas na cultura do sistema de saúde brasileiro, não são reconhecidas como danos iatrogênicos na atenção obstétrica, acometendo lesões a neonatos e parturientes. Em todos os acórdãos analisados envolvendo demora no atendimento ao parto houve sequelas físicas ao nascituro, gerando lesões irreversíveis nos mesmos e em outros casos a morte, culminando em danos morais e/ou materiais estipulados nas ações judiciais; não obstante, há ainda os danos de ordem psicológica enfrentados pelos pais em virtude das graves lesões aos filhos devido as falhas precárias no sistema de saúde.

\section{Episiotomia}

A episiotomia caracteriza-se por um procedimento cirúrgico realizado pelos médicos para aumentar a abertura do canal vaginal com uma incisão realizada na vulva, cortando a entrada da vagina com uma tesoura ou bisturi, algumas vezes sem anestesia. A cirurgia afeta diversas estruturas do períneo, tais como os músculos, vasos 
sanguíneos e tendões, gerando em alguns casos, posterior incontinência urinária e fecal na mulher, além de provocar outras complicações, dentre elas a dor nas relações sexuais, risco de infecção e laceração perineal em partos subsequentes, maior volume de sangramento durante o período menstrual, além dos resultados estéticos insatisfatórios. (PREVIATTI; SOUZA, 2007).

Diante do cenário, Previatti e Souza postulam que:

É fato que a episiotomia vem sendo utilizada de forma indiscriminada na assistência obstétrica. É fato também que, os profissionais de saúde arraigados a conceitos e práticas que não contemplam os resultados de evidências científicas atuais, bem como, as práticas baseadas nos direitos das mulheres, insistem na realização deste procedimento, mantêm um enfoque intervencionista e assim subtraem da mulher-parturiente a possibilidade de experienciar o parto, como um processo fisiológico e fortalecedor de sua autonomia. (2007, p. 198).

A episiotomia é a única cirurgia do Brasil, realizada sem o consentimento da paciente e sem tampouco a informação sobre os riscos, possíveis benefícios e efeitos adversos, contrariando os preceitos da Medicina Baseada em Evidências (BEM). (CIELLO et al, 2012).

A pesquisa "Nascer no Brasil: Inquérito Nacional sobre Parto e Nascimento"11 estima que a episiotomia seja realizada em 53,5\% dos partos via vaginal no Brasil, enquanto a recomendação da OMS é que seja realizada em 10\% deles. No caso de primíparas, o índice chega a 74\%. Na América Latina, as taxas podem atingir 90\% dos casos e apesar de ser uma prática comum no cenário obstétrico, o procedimento foi introduzido na rotina obstétrica sem qualquer evidência científica sobre sua efetividade, razão pela qual se pretende torná-la uma técnica restrita e não mais rotineira em obstetrícia. (ZANETTI et al., 2009).

Conforme Diniz (2003) o uso indevido da episiotomia e da posterior costura (episiorrafia) é um exemplo de violação do direito humano de estar livre de tratamentos cruéis, humilhantes e degradantes. Desta forma, na fala dos profissionais, repete-se constantemente a crença de que sem uma sutura adicional conhecida como "ponto do marido", o parceiro se desinteressaria sexualmente pela mulher.

Com relação a essa prática identificou-se um acórdão ilustrativo das iatrogenias que podem advir da mesma. Em virtude de episiotomia, a parturiente foi acometida por lesão esfincteriana grave gerando incontinência fecal e urinária.

E M E N T A: RESPONSABILIDADE CIVIL OBJETIVA DO PODER PÚBLICO ELEMENTOS ESTRUTURAIS - PRESSUPOSTOS LEGITIMADORES DA INCIDÊNCIA DO ART. 37, $\$ 6^{\circ}$, DA CONSTITUIÇÃO DA REPÚBLICA - TEORIA DO RISCO ADMINISTRATIVO - HOSPITAL PÚBLICO QUE INTEGRAVA, À ÉPOCA DO FATO GERADOR DO DEVER DE INDENIZAR, A ESTRUTURA DO

\footnotetext{
${ }^{11}$ Pesquisa coordenada pela Fundação Oswaldo Cruz e realizada com a participação de renomados pesquisadores de várias instituições científicas, sendo a primeira a oferecer um panorama nacional sobre a situação de atenção ao parto e nascimento no Brasil. No total, 23.894 mulheres foram entrevistadas em maternidades públicas, privadas e mistas (maternidades privadas conveniadas ao Sistema Único de Saúde - SUS). A coleta de dados se iniciou em fevereiro de 2011 e terminou em outubro de 2012.
} 
MINISTÉRIO DA SAÚDE - RESPONSABILIDADE CIVIL DA PESSOA ESTATAL QUE DECORRE, NA ESPÉCIE, DA INFLIÇÃO DE DANOS CAUSADA A PACIENTE EM RAZÃO DE PRESTAÇÃO DEFICIENTE DE ATIVIDADE MÉDICOHOSPITALAR DESENVOLVIDA EM HOSPITAL PÚBLICO - LESÃO ESFINCTERIANA OBSTÉTRICA GRAVE - FATO DANOSO PARA A OFENDIDA RESULTANTE DE EPISIOTOMIA REALIZADA DURANTE O PARTO - OMISSÃO DA EQUIPE DE PROFISSIONAIS DA SAÚDE, EM REFERIDO ESTABELECIMENTO HOSPITALAR, NO ACOMPANHAMENTO PÓSCIRÚRGICO - DANOS MORAIS E MATERIAIS RECONHECIDOS RESSARCIBILIDADE - DOUTRINA - JURISPRUDÊNCIA - RECURSO DE AGRAVO IMPROVIDO. (AI 852237 AgR, Relator(a): Min. CELSO DE MELLO, Segunda Turma, Data do julgamento: 25 junho de 2013, Data da publicação: 06 de setembro de 2013, p. 1, grifo nosso).

A episiotomia de rotina é considerada uma prática associada à violência obstétrica ocasionando uma série de complicações à parturiente. Sua prática implica em ser computado procedimento adicional além do parto, também definindo mais dias de internação hospitalar, o que acaba gerando mais lucratividade para médicos e instituições hospitalares. Ademais, serve como oportunidade de treinamento prático para os médicos residentes na área. (KONDO et al, 2014).

No Brasil, um dos principais argumentos usados a favor tanto da episiotomia quanto da cesárea de rotina é o de que o parto vaginal torna os músculos vaginais flácidos, comprometendo os atrativos sexuais da mulher. No entanto, segundo evidência científica, a episiotomia de rotina danifica as estruturas vaginais mais do que as protege. [...]As mulheres aceitam a episiotomia de rotina no Brasil porque a maioria acredita que ela seja necessária, do ponto de vista médico, para proteger sua saúde e a do bebê. Como a episiotomia é uma decisão do médico, as mulheres presumem que este está fazendo a coisa mais correta. Se a mulher acreditar que terá problemas sexuais e uma vagina flácida depois do parto normal, e que a episiotomia é solução para isto, ela concorda. (DINIZ; CHACHAM, 2006, p. 86-87)

No acórdão analisado, por exemplo, a episiotomia ocasionou uma lesão esfincteriana grave à paciente, advinda do trauma obstétrico, resultando em incontinência fecal, o que perturbou o equilíbrio emocional, social e psicológico da paciente, uma vez que afetou negativamente seu convívio social, restringindo-o. Analisando o inteiro teor do acórdão é possível inferir justamente, o caráter omissivo configurado nas práticas obstétricas de episiotomia e os sintomas dela advindos na vida da parturiente:

As circunstâncias do presente caso evidenciam que o nexo de causalidade material restou plenamente configurado em face do comportamento omissivo em que incidiu o Poder Público, que se absteve de "(...) orientar a autora sobre o procedimento adotado no seu parto, assim como os eventuais riscos a que estaria exposta, como também a necessidade do seu retorno ao hospital para o acompanhamento médico de sua situação. (fls. 329). Lamentavelmente, essa incompreensível omissão estatal foi causa do evento danoso. (...) teve que se afastar de suas atividades laborais, devido a sua incontinência fecal, tendo que se submeter, posteriormente, a um procedimento cirúrgico para a reparação de seu problema (fls. 328). (AI 852237 AgR, Relator(a): Min. CELSO DE MELLO, Segunda Turma, Data do julgamento: 25 junho de 2013, Data da publicação: 06 de setembro de 2013, p. 5-6, grifo nosso).

Por óbvio, nem todas as condutas relacionadas às práticas obstétricas podem ser enquadradas como violência obstétrica, ao passo que há situações de caráter emergencial que devem ser adotadas com escopo de 
salvar a parturiente e o nascituro.

Entretanto, condutas com relação à episiotomia devem ser analisadas com cautela a fim de seja devidamente averiguado se a gestante foi devidamente informada ou não no ato de sua realização. Analisando o inteiro teor do acórdão, percebe-se que houve omissão do Poder Público em orientar a autora sobre o procedimento adotado no seu parto, assim como os eventuais riscos aos quais estaria exposta. Ademais, no caso em tela, tem-se o agravante da lesão que impediu a parturiente ao convívio social normal.

Nesse sentido, resta clara a violência obstétrica diante da perda de autonomia da parturiente em ser protagonista do seu parto, através de uma intervenção danosa que afetou consideravelmente sua qualidade de vida, prejudicando a sua integridade física, psíquica e sexual.

Infelizmente, verifica-se ainda, hipossuficiência técnica por parte dos julgadores para aquilatar devidamente este tipo de violência, uma vez que em suas decisões deixam de contemplar a violência psicológica sofrida pela parturiente nos contextos avaliados, além de não evidenciarem a ocorrência da violência obstétrica. $O$ caso em questão, por exemplo, limita-se apenas a discutir a responsabilidade civil da administração pública.

\section{Manobra de Kristeller}

A manobra de Kristeller é usada com frequência nos hospitais com a finalidade de acelerar a expulsão do feto. Consiste em uma manobra na parte superior do útero, durante as contrações do parto, visando empurrar o nascituro em direção à pelve. Utiliza-se as mãos, braço, antebraço, joelho, e em casos mais absurdos, profissionais de saúde sobem sobre o abdômen da parturiente. É conhecida como "manobra invisível", posto que raramente é mencionada em prontuário médico. (DINIZ, 2009; PARIENTE, 2013).

O fato consiste num flagrante desrespeito à integridade física da mulher e nos casos mais comuns pode provocar: lesão dos órgãos internos, hematomas, fratura de costelas, hemorragias e contusões. Além disso, gera violência psicológica à gestante. Ademais, expõe a criança ao aumento da probabilidade de complicações decorrentes de distócia de $\operatorname{ombros}^{12}$, fratura de clavícula, trauma encefálico, descolamento do músculo esternocleidomastoideo ${ }^{13}$, hipóxia ${ }^{14}$, dentre outras sequelas. (GARCIA et al, 2013).

A pesquisa "Nascer no Brasil: Inquérito Nacional sobre Parto e Nascimento", constatou que essa violação acomete aproximadamente 36,1\% das mulheres. A OMS desenvolveu uma classificação das práticas comuns na condução do parto, sendo a manobra de Kristeller enquadrada na categoria C como prática ineficaz,

\footnotetext{
${ }^{12}$ A distócia de ombro (DO) é a necessidade de utilização de manobras obstétricas para desprendimento dos ombros durante o parto vaginal, podendo ocasionar algumas complicações maternas e fetais como lacerações do canal de parto, fratura de clavícula e outras lesões. (TEIXEIRA et al, 2012).

${ }^{13}$ É um músculo da face lateral do pescoço, na região anterolateral. É o principal flexor do pescoço.

${ }^{14}$ Sofrimento para o feto com diminuição ou ausência de oxigênio necessário ao feto por meio da placenta.
} 
sem evidência científica para utilização e usada de forma inadequada. (GIGLIO; FRANÇA, LAMOUNIER, 2011). Além disso, o Ministério da Saúde na publicação "Parto, Aborto e Puerpério: Assistência Humanizada para a Mulher" (2001) também descreve o procedimento como prática claramente prejudicial ou ineficaz e que deve ser eliminada.

Ademais, em 23 de janeiro de 2017, o Conselho Federal de Enfermagem (COFEN) homologou, por unanimidade, a decisão 95/2016 do Coren-RS, que proíbe a participação de profissionais de Enfermagem na manobra de Kristeller.

Durante a pesquisa foram identificados dois acórdãos ${ }^{15}$ que melhor ilustram a situação violadora, conforme se depreende abaixo:

No particular, a conduta estatal restou evidenciada pela condução do parto forçado com utilização de fórceps e Kristeller, quando possível a adoção de melhores técnicas para preservar a integridade fisica da criança, sendo que, em virtude de manobras médicas realizadas, a menor nasceu com sequelas. Registre-se que, inicialmente, o parto seria realizado mediante cesárea, tendo sido alterado para aquela modalidade. Note-se, também, que o réu não apresentou qualquer justificativa a respeito da motivação que ensejou a alteração abrupta da modalidade de parto. Ao lado disso, não se pode olvidar que a "manobra de Kristeller, consistente em pressionar manualmente o fundo do útero da parturiente, com o objetivo de abreviar o período expulsivo, constitui técnica perigosa e vedada pelo próprio sistema público, conforme Protocolos de Urgência e Emergência da Secretaria de Saúde do Distrito Federal. O dano, por seu turno, também sobressai incontroverso. De acordo com a documentação juntada aos autos, durante o parto da autora ocorreu dificuldades na extração dos ombros (distócia de ombros) que deu causa à lesão do plexo braquial esquerdo. [... No particular, ao contrário do que afirmou o réu, o sofrimento, físico e moral decorrente da adoção de procedimentos equivocados verificados durante o trabalho de parto certamente gerou dor irreparável à menor, além, de causar profundo abalamento em sua dignidade e esfera íntima, não existindo, por certo, meios de recompor a situação ao status quo ante. Com efeito, as sequelas físicas e psicológicas deixadas na oportunidade do seu nascimento e que a acompanharão durante o resto da vida, reduzindothe a qualidade de vida, são capazes de vilipendiar seus atributos da personalidade. Em suma: a integridade física e mental da autora foram frontalmente violadas a lhe impingir prejuízo de ordem moral, concernente no abalo psíquico e estético, razão pela qual não merece reparos a r. sentença impugnada que reconheceu seu direito a uma compensação pecuniária a esse título. (AgRg no AgRg no AGRAVO EM RECURSO ESPECIAL No 672.584 - DF, Relator: Min. OG Fernandes, Segunda Turma, Data do julgamento: 22 setembro de 2015, Data da publicação: 07 de outubro de 2015, p. 2-3, grifo nosso).

ADMINISTRATIVO. AGRAVO REGIMENTAL. RESPONSABILIDADE CIVIL DO ESTADO. FALHA NA PRESTAÇÃO DE SERVIÇO MÉDICO-HOSPITALAR. PARTO QUE RESULTOU EM SEQUELAS AO MENOR. PARALISIA CEREBRAL. USO DE FÓRCEPS (MANOBRA DE KRISTELLER). (AgRg no AGRAVO EM RECURSO ESPECIAL No 628.542 - RJ, Relator: Min. Sérgio Kukina, Primeira Turma, Data do julgamento: 05 de fevereiro de 2015, Data da publicação: 13 de fevereiro de 2015, p. 1).

Conforme Carvalho (2014), não se verifica qualquer benefício materno ou fetal para aplicação da

\footnotetext{
${ }^{15} \mathrm{AgRg}$ no AgRg no AGRAVO EM RECURSO ESPECIAL 672.584 - DF e AgRg no AGRAVO EM RECURSO ESPECIAL $628.542-\mathrm{RJ}$.
} 
manobra de Kristeller, mas sim, riscos associados ao aumento das taxas de episiotomia, lacerações no períneo, aumento da dor perineal e dispareunia ${ }^{16}$ em um período pós-parto, além das sequelas físicas ao neonato, conforme se depreende dos acórdãos analisados.

\section{Outros casos envolvendo erro médico}

A atividade profissional médica, em regra geral ${ }^{17}$, constitui-se como obrigação de meio, ou seja, o agente se obriga a empreender a atividade, sem garantir, todavia, o resultado esperando. Entretanto, deve usar de prudência e diligências normais para a prestação devida do serviço, utilizando as melhores técnicas, objetivando alcançar um determinado resultado. A responsabilidade civil dos profissionais de saúde é observada a partir da verificação da culpa, comprovando-se que agiram com negligência, imprudência ou imperícia.

Foram analisados quatro acórdãos dos quais o erro médico ensejou em perda total ou parcial do útero ${ }^{18}$. Conforme Melo e Barros, o útero é "órgão feminino comumente investido de grande carga afetiva e vinculado à fertilidade e sexualidade, sendo considerado importante representante da feminilidade" (2009, p. 80). Sua extração pode desencadear fortes mudanças refletidas no corpo, no psiquismo e no social da paciente.

Nenhuma das parturientes apresentadas nos julgados analisados apresentava quaisquer problemas para que houvesse a necessidade da cirurgia de histerectomia ${ }^{19}$, mas foram acometidas pela extração em decorrência de um "erro médico", sendo o fato considerado uma violência obstétrica uma vez que houve extirpação do elemento crucial do processo reprodutivo dessas mulheres.

Há ainda acórdãos ${ }^{20}$ relacionados a "erro médico" em virtude da aplicação de substâncias indutoras do parto, sendo a mais comum delas, a ocitocina.

A ocitocina é um hormônio que aumenta o processo de contrações uterinas acelerando o trabalho de parto. Entretanto, o próprio corpo se encarrega de produzi-lo. A ocitocina sintética (artificial) usada de maneira indiscriminada apenas para acelerar o trabalho de parto, sem indicação correta, aplicada no soro da parturiente, causa o aumento significativo das dores durante as contrações e, se não for controlada pode causar sérias complicações para à mulher e o neonato, podendo levar desde a dor e sofrimento desnecessários ao aumento excessivo da frequência cardíaca da parturiente, além de causar dificuldades na oxigenação do bebê, bem como

\footnotetext{
${ }^{16}$ Dor genital recorrente ou persistente associada ao intercurso sexual. (FERREIRA et al, 2007, p. 694).

${ }^{17}$ Em se tratando de cirurgia plástica de natureza estética, haverá, segundo doutrina majoritária, obrigação de resultado, desta forma, o médico deverá produzir o resultado esperado. Em se tratando de cirurgia plástica reparadora, a exemplo dos casos de queimadura, a obrigação será de meio.

${ }^{18}$ RECURSO ESPECIAL 740.574 - SP; AgRg no AGRAVO EM RECURSO ESPECIAL 144.794 - RJ; AgRg nos EDcl no AGRAVO DE INSTRUMENTO 854.005 - MT e RECURSO ESPECIAL 1.174.490 - MA.

${ }^{19}$ Extração cirúrgica do útero.
} 
dano cerebral ao mesmo.

Conforme Diniz (1996) a utilização rotineira do fórceps e da aplicação de ocitocina sintética é relacionado ao esvaziamento das enfermarias no pré-parto. Desta forma, "a dor como resultado da iatrogenia pode confundir-se com a dor inerente do próprio trabalho de parto fisiológico" (ZORZAM, 2013, p. 104).

Em pesquisa realizada por Zorzam (2013), em todos os relatos das mulheres entrevistadas, a ocitocina apresentou-se como a intervenção mais dolorosa sofrida durante o parto e nenhuma delas soube informar se havia ocitocina no soro prescrito durante seu trabalho de parto, o que também sugere negligência dos profissionais quanto ao direito do consentimento informado das pacientes sob seus cuidados.

Nesse sentido, imprescindível a exposição dos riscos da substância à parturiente, cabendo-lhe a decisão sobre a aplicação ou não, implicando o ato em violação ao direito de informação, resguardado no art. $5^{\circ}$ da $\mathrm{CRFB} / 88$ como um direito fundamental, sendo constantemente negligenciado nas práticas associadas a violência obstétrica.

Todas as mulheres têm direito a receber informações sobre o seu estado de saúde e sobre os procedimentos indicados, em linguagem clara, de modo respeitoso e compreensível. O profissional de saúde tem o dever de explicar a finalidade de cada intervenção ou tratamento, assim como os riscos ou possíveis complicações e as alternativas disponíveis. Com base nessas informações, a mulher tem o direito de recusar tratamentos ou procedimentos em seu corpo, o que se chama direito à recusa informada. (KONDO et al, 2014, 2014, p. 5).

Nesse sentido, deixar de prestar informações sobre o estado de saúde da mulher, não explicando claramente acerca dos procedimentos que serão realizados e não dar oportunidade para a mulher refletir e decidir se deseja ou não submeter-se a um determinado procedimento configura-se como exemplo de violência no atendimento obstétrico. (KONDO et al, 2014).

Em outro caso relacionado ao direito de informação e consentimento da parturiente, o nosocômio remeteu o natimorto a outra entidade sem anuência da mãe, resultando em perda do cadáver. Não bastasse a perda de um filho ser uma situação extremamente dolorosa, a parturiente ainda experienciou danos psicológicos profundos em virtude da falha no dever de informar, conforme se depreende abaixo:

RECURSO ESPECIAL. CIVIL. PROCESSUAL CIVIL. AÇÃO INDENIZATÓRIA POR DANO MORAL. PARTO GEMELAR. UM NATIMORTO. DESAPARECIMENTO DO CADAVER. RESPONSABILIDADE DO NOSOCOMMIO PELA GUARDA DOS RESTOS MORTAIS. IMPOSSIBILIDADE DE SEPULTAMENTO. OFENSA MORAL. [...] violação do dever de guarda do cadáver de natimorto, extraviado, gera responsabilidade por dano moral passível de reparação, tendo em vista que provoca nos familiares dor profunda com a ausência dos restos mortais, a impossibilitar o sepultamento de ente querido, além de violar o direito à dignidade da pessoa morta. [...] Responsabilidade pelo desaparecimento do corpo insepulto do filho natimorto da autora a partir de remessa não autorizada - Completo descabido na alegação do nosocômio réu de dever da autora em

${ }^{20}$ AgRg no AGRAVO EM RECURSO ESPECIAL 442.266 - SP e AgRg no AGRAVO EM RECURSO ESPECIAL 180.480 SP. 
tentar recuperar o corpo de seu filho natimorto para onde fez a remessa não autorizada. [...] o nosocômio réu efetiva o parto; atesta a circunstância de natimorto; manda o cadáver para outra entidade, sem anuência da mãe, no estado puerperal e sob as condições psicológicas de perda de um filho; o corpo do natimorto some, e a responsabilidade estaria com a autora que não o teria reclamado na outra instituição. Completamente estapafúrdia essa alegação. Se o nosocômio réu mandasse o cadáver com a finalidade do exame anatomopatológico para outro país, então que a autora fosse para lá tentar reaver o filho natimorto para o sepultamento. Não parece crível a ousadia dessa afirmação. Caso o contrato com laboratório se referisse a uma universidade em Pequim, que a autora então fosse para a China tentar reaver o corpo de seu filho. Essa postura é um completo descabido. Considero que a impossibilidade de lavratura do assento de natimorto do filho da autora e o sumiço do cadáver do feto devem-se à postura ilícita e temerária do nosocômio réu, que arca com os danos morais. (RECURSO ESPECIAL No 1.351.105 - SP (2012/0226484-7, Relator: Min. Raul Araújo, Data de julgamento: 06 de junho de 2013, Data da publicação: 20 de junho de 2013, p. 1;3; 11, grifo nosso).

Nesse sentido, após análise dos acórdãos elencados, resta clara a violação dos direitos humanos vilipendiados cotidianamente contra as parturientes, sendo clara a tipificação da violência obstétrica nos acórdãos dos tribunais superiores. Todas as situações violadoras decorrentes das práticas de violência obstétrica têm efeitos físicos e emocionais significativos na vida das mulheres. Em decorrência das iatrogenias praticadas na seara médica, muitas mulheres morrem, outras carregam, para sempre, sequelas físicas e psicológicas impostas a elas e ou a seus filhos.

Salienta-se, que a ausência de legislação específica não impede que os aplicadores do Direito possam punir a prática, uma vez que resta caracterizada a violação de princípios e direitos basilares do Estado Democrático de Direito, podendo haver a aplicação da responsabilidade civil da equipe hospitalar e do Estado (art. 927 e seguintes do CC/02) ou ainda aplicação da lei penal em caso de constrangimento ilegal (art. 146, CP), lesão corporal (art. 129, CP) ou homicídio (art. 121, CP).

Em todos os acórdãos analisados, houve a imputação da responsabilidade subjetiva do médico e/ou objetiva do hospital ou poder público, refletindo os ilícitos praticados contra as parturientes.

Conforme já exposto, para apuração da responsabilidade civil dos médicos e enfermeiros deve haver verificação da culpa, só havendo responsabilização se comprovado que tenham agido com negligência, imprudência e imperícia: "a responsabilidade pessoal dos profissionais liberais será apurada mediante a verificação de culpa”. (Art. 14, \$ 40 do Código de Defesa do Consumidor)

Entretanto, há hipóteses em que não há necessidade de comprovação de culpa, o que caracteriza-se como responsabilidade civil objetiva. Nessa espécie de responsabilidade, o dolo ou culpa na conduta do agente causador do dano é irrelevante juridicamente, haja vista que faz-se necessário somente a existência do nexo de causalidade entre o dano e a conduta do agente causador do ato ilícito, para que surja o dever de indenizar.

Assim, no que se refere a relação entre o hospital ou clínica médica que presta serviços, a responsabilidade civil é objetiva, por força do art. 932, III, do CC/2002: "São também responsáveis pela 
reparação civil: III - o empregador ou comitente, por seus empregados, serviçais e prepostos, no exercício do trabalho que lhes competir, ou em razão dele". Se o erro ou falha médica ocorrer em hospital ou outro estabelecimento público, a responsabilidade será do Estado.

\section{CONSIDERAÇÕES FINAIS}

A partir do estudo proposto, constatou-se que a violência obstétrica corresponde a uma forma da violência de gênero específica, tendo em vista que abrange condutas e/ou omissões perpetradas pelos profissionais de saúde no controle do corpo e da sexualidade das mulheres, além de estar dominada por significados culturais estereotipados de desvalorização e subserviência delas em um momento de vulnerabilidade emocional muito específico.

Nesse sentido, faz-se mister ressaltar a importância de que em tais casos, os agentes do sistema de justiça, em especial, a magistratura, busquem analisar tais processos sob uma perspectiva de gênero, conforme preconizado nos tratados internacionais de direitos humanos das mulheres. Para que a experiência do parto possa ser de fato prazerosa, não basta que a mulher e o bebê sobrevivam, mas que as garantias de um tratamento digno, respeitoso, humanizado e com práticas embasadas em evidências, respeitando-se ainda a autonomia da mulher, sejam levadas seriamente em consideração.

A violência obstétrica como forma de violência de gênero deve ser difundida, sobretudo através de seu reconhecimento em decisões judiciais, uma vez que em função da sua condição de intensa vulnerabilidade durante a gestação, cada vez mais mulheres sofrem este tipo de violência, ainda pouco reconhecida. Infelizmente, os julgados sequer mencionam o termo "violência obstétrica", o que favorece a invisibilidade do fenômeno no curso do processo judicial.

Além disso, a ausência de instrumentos próprios para identificar e notificar a violência obstétrica corroboram para invisibilização do problema tanto na esfera social quanto jurídica. Ademais, os serviços que funcionam atualmente não se encontram de todo preparados para receber denúncias de violação no tratamento obstétrico.

Mesmo não havendo menção do termo "violência obstétrica" nos julgados analisados, percebe-se amplamente os danos iatrogênicos e as violações dos direitos humanos das mulheres em cada um deles. Nessa esteira, faz-se necessário pleitear a capacitação continuada dos magistrados e demais operadores do direito para que possam compreender melhor a temática e assim aprofundar seus conhecimentos transdisciplinares a fim de que sejam proferidas decisões melhor embasadas tecnicamente e com as sanções devidas à gravidade dos casos trazidos em juízo.

Percebe-se ainda a necessidade de divulgação do tema por meio de políticas públicas de prevenção, bem 
como a necessidade de conscientização da população em geral acerca do parto humanizado, para que as parturientes possam efetivamente reconhecer e passar a pleitear seus direitos, pois, infelizmente, o número expressivo de mulheres que sofrem violência obstétrica ainda não pode ser mensurado ou sequer inferido e/ou estimado através dos casos que chegam aos tribunais.

Ademais, a problemática carece de leis e diretrizes para assegurar uma assistência humanizada no momento do parto, cabendo, portanto, aos entes estatais, a elaboração de leis específicas para combater este tipo de violência de gênero. Insta ainda salientar, a importância da capacitação continuada dos profissionais da área de saúde que contemple uma visão social e humanística de suas atuações, incluindo-se o reconhecimento de direitos dos pacientes, de modo a oferecer à parturiente um processo de atenção adequado no ciclo gravídico-puerperal.

Infelizmente, os julgados ainda permanecem silentes diante da amplitude do panorama iatrogênico da violência obstétrica. Apesar da possibilidade de imputação da responsabilidade civil aos executores, bem como das devidas indenizações às vítimas, há ainda a difícil tarefa em comprovar o nexo de causalidade entre a conduta médico-hospitalar e o dano. Ademais, as autoras dos processos, desejam, de fato, que seja reconhecida judicialmente a violência praticada por tais agentes, não simplesmente como erro médico, como foi possível perceber na maioria dos acórdãos analisados, mas sim como violência de gênero, especificando claramente a violência obstétrica.

\section{OBSTETRIC VIOLENCE IN BRAZIL: AN APPROACH CONSIDERING THE STF AND STJ JUDGMENTS}

\section{Abstract}

This paper aims to analyze and discuss the phenomenon of obstetric violence in Brazil, based on the analysis of the judgments of the Supreme Federal Court (STF) and the Superior Court of Justice (STJ), also proposing a reflection on the way the judiciary acts in such cases. A quantitative-qualitative approach was used as well as the methodological procedure of documentary analysis through the evaluation of the judgments considered in this paper. Exploratory searches were carried out through keywords related to obstetric violence in the websites of the respective courts between 2007 and 2016. The judgments which caused more evidence about the theme were selected and discussed.

Keywords: Obstetric Violence; Parturients; Rights; Women.

\section{REFERENCIAS}

AGUIAR, Janaína Marques de. Violência institucional em maternidades públicas: hostilidade ao invés de 
acolhimento como uma questão de gênero. Disponível em: <http://www.apublica.org/wpcontent/uploads/2013/03/JanainaMAguiar.pdf>. Acesso em: 02 nov. 2015.

ZANETTI, Miriam Raquel Diniz et al. Episiotomia: revendo conceitos. Femina, Rio de Janeiro, v. 37, n. 7, p. $367-$ 371, jul. 2009. Disponível em: <http://www.febrasgo.org.br/site/wpcontent/uploads/2013/05/feminav37n7p367-71.pdf>. Acesso em: 16 mar. 2015

BRASIL. Constituição da República Federativa do Brasil de 1988. Disponível em: <http://www.planalto.gov.br/ccivil_03/constituicao/constituicao.htm>. Acesso em: 27 out. 2015.

Convenção Interamericana para prevenir, punir e erradicar a Violência contra a Mulher. Convenção de

Belém do Pará. 1994. Disponível em: <http:// www.cidh.oas.org/basicos/portugues/m.Belem.do.Para.htm>. Acesso em: 13 jan. 2017.

Defensoria Pública do Estado de São Paulo. Violência obstétrica: você sabe o que é?. Escola da Defensoria Pública do Estado: São Paulo, 2013. Disponível em: <http://www.defensoria.sp.gov.br/dpesp/repositorio/41/violencia\%20 obstetrica.pdf $>$. Acesso em: 10 dez. 2015.

Lei 8.078, de 11 de setembro de 1990. Dispõe sobre a proteção do consumidor e dá outras providências. Disponível em: <http://www.planalto.gov.br/ccivil_03/leis/L8078.htm>. Acesso em: 27 out. 2015.

Lei 11.108, de 7 de Abril de 2005. Altera a Lei no 8.080, de 19 de setembro de 1990, para garantir às parturientes o direito à presença de acompanhante durante o trabalho de parto, parto e pós-parto imediato, no âmbito do Sistema Único de Saúde - SUS. Brasília: 2005. Disponível em: <http://www.planalto .gov.br/ccivil_03/_Ato2004 2006/2005/Lei/L11108.htm>. Acesso em: 13 jan. 2017.

Lei 11.634, de 27 de setembro de 2007. Dispõe sobre o direito da gestante ao conhecimento e a vinculação à maternidade onde receberá assistência no âmbito do Sistema Único de Saúde. Disponível em: <http://www.planalto.gov.br/ccivil_03/_Ato2007-2010/2007/Lei/L11634.htm>.Acesso em: 15 jan. 2017.

Ministério da Saúde. Secretaria de Políticos de Saúde. Área Técnica de Saúde da Mulher. Parto, aborto e puerpério: assistência humanizada à mulher/Ministério da Saúde, Secretaria de Políticas de Saúde, Área Técnica da Mulher. - Brasília: Ministério da Saúde, 2001. Disponível em: <http://pfdc.pgr.mpf.mp.br/temas-deatuacao/mulher/saude-das-mulheres/enfrentamento-a-mortalidade-materna-menu/parto-aborto-e-puerperioassistencia-humanizada-a-mulher-ms $>$. Acesso em: 04 nov. 2015.

Projeto de lei 7633/2014. Dispõe sobre a humanização da assistência à mulher e ao neonato durante o ciclo gravídico-puerperal e dá outras providências. Brasília, 27 de maio de 2014. Disponível em: $<$ http://www.camara.gov.br/sileg/integras/1257785.

pdf>. Acesso em: 13 jan. 2017.

Organização Mundial de Saúde. Prevenção e eliminação de abusos, desrespeito e maus-tratos durante o

parto em instituições de saúde. 2014. Disponível em:
<http://apps.who.int/iris/bitstream/10665/134588/3/WHO_RHR_14.23

_por.pdf>. Acesso em: 04 nov. 2015.

BEUREN, IIse Maria. Como elaborar trabalhos monográficos em contabilidade: teoria e prática. Atlas, 2006.

CARVALHO, Laëtitia Cristina Varejão. Os efeitos da manobra de Kristeller no segundo período de trabalho de
$\begin{array}{lll}\text { parto. } & \text { Disponível } & \mathrm{em}:\end{array}$ https://comum.rcaap.pt/bitstream/10400.26/9509/1/Relat\%C3\%B3rio\%20Est\%C3\%A1gio\%20Final\%20La\% C3\%ABtitia\%20Carvalho.pdf>. Acesso em: 11 jan. 2017.

CHAUÍ, Marilena. Participando do debate sobre mulher e violência. In: Perspectivas antropológicas da mulher. Rio de Janeiro: Zahar, 1985. 
CIELLO, Cariny et al. Parto do princípio. Mulheres em Rede pela Maternidade Ativa. Dossiê da Violência Obstétrica "Parirás com dor". Disponível em: <https:/ /www.senado.gov.br/ comissoes/documentos/SSCEPI/DOC\%20VCM\%20367.pdf>. Acesso em: 10 dez. 2015.

DIAS, Marcos Augusto Bastos; DESLANDES, Suely Ferreira. Expectativas sobre a assistência ao parto de mulheres usuárias de uma maternidade pública do Rio de Janeiro, Brasil: os desafios de uma política pública de humanização da assistência. Cad. Saúde Pública, Rio de Janeiro, 22(12):2647-2655, dez, 2006. Disponível em: <http://www.scielo.br/pdf/csp/v22n12/13.pdf>. Acesso em: 15 jan. 2017.

DINIZ, Simone Carmen Grilo. Assistência ao parto e relações de gênero: elementos para uma releitura médicosocial. 1996. Dissertação (Mestrado em Medicina Preventiva) - Faculdade de Medicina, Universidade de São Paulo, São Paulo.

DINIZ, Simone Carmen Grilo. Campanha pela abolição da episiotomia de rotina. 2003. Disponível em: <http://www.amigasdoparto.com.br/episiotomia3.html>. Acesso em: 10 dez. 2015.

DIAS, Simone Grilo; CHACHAM, Alessandra S. O 'corte por cima' e o 'corte por baixo': o abuso de cesáreas e episiotomias em São Paulo. Questões Saúde Reprod., v.1, n.1, p.80-91, 2006. Disponível em: < https://edisciplinas.usp.br/pluginfile.php/2795253/mod_resource/content/1/O\%20_corte\%20por\%20cima _\%20e\%20o\%20_corte\%20por\%20baixo_\%20o\%20abuso\%20de\%20cesa_reas\%20e\%20episiotomias\%20em\% 20Sa_o\%20Paulo\%20\%281\%29.pdf>. Acesso em: 15 jan. 2017.

FERREIRA, Ana Laura Carneiro Gomes et al. Disfunções sexuais femininas. FEMINA, Novembro 2007, vol 35, no 11. Disponível em: <http://www.febrasgo.org.br/site/wp-content/uploads/2013/05/FEMINA_Novembro691.pdf>. Acesso em: 13 jan. 2017.

FOUCAULT, Michel. Microfisica do Poder. O nascimento do hospital. 3. ed. Rio de Janeiro: Edições Graal, 1982.

O Sujeito e o poder. In: Rabinow P, Dreyfus HL, Foucault M. Uma trajetória filosófica para além do estruturalismo e da hermenêutica. Rio de Janeiro: Forense Universitária; 1995.

FONEITE, Josmery; FEO, Alejandra; MERLO, Judith Toro. Grado de conocimiento de violencia obstétrica por el personal de salud. Revista de Obstetricia y Ginecología de Venezuela. v. 72, n.1, Caracas: março, 2012. Disponível em: <http://www.scielo.org.ve/ scielo.php?script=sci_arttext\&pid=S004877322012000100002\&lng=es\&nrm=iso\&tlng=es $>$. Acesso em: 02 nov. 2015.

GARCIA, Begonã et al. Dossier STOP Kristeller: riesgos para la madre y el bebé. Disponível em: $<$ https://www.elpartoesnuestro.es/informacion/dossier-stop-kristeller-riesgos-para-la-madre-y-el-bebe>. Acesso em: 14 jan. 2017.

GIGLIO, Margareth Rocha Peixoto; FRANÇA, Elisabeth; LAMOUNIER, Joel Alves. Avaliação da qualidade da assistência ao parto normal. Rev Bras Ginecol Obstet. 2011; 33(10):297-304. Disponível em: <http://www.scielo.br/pdf/rbgo/v33n10/05.pdf>. Acesso em: 14 jan. 2017.

KONDO, Cristiane Yukiko et al. Episiotomia "é só um cortezinho": violência obstétrica é violência contra a mulher: mulheres em luta pela abolição da violência obstétrica. 1 ed. São Paulo: Parto do Princípio; Espírito Santo: Fórum de Mulheres do Espírito Santo, 2014. Disponível em: 
<http://www.sentidosdonascer.org/wordpress/wp-content/themes/sentidos-donascer/assets/pdf/controversias/Episiotomia.pdf>. Acesso em: 15 nov. 2016.

KRONBAUER, José Fernando Dresch e MENEGHEL, Stela Nazareth. Perfil da violência de gênero perpetrada por companheiro. Disponível em: < http://www.scielo.br/pdf/rsp/v39n5/26287.pdf> Acesso em: 01 jun. 2014.

LEAL, M.C.; GAMA, S.G.N et al. Nascer no Brasil: Inquérito Nacional sobre Parto e Nascimento. Disponível em: $<$ http://www.ensp.fiocruz.br/portal-ensp/informe/site/arquivos/anexos/nascerweb.pdf $>$. Acesso em: 15 nov. 2015.

MELO, Mônica Cristina Batista de; BARROS, Érika Neves de. Histerectomia e simbolismo do útero: possíveis repercussões na sexualidade feminina. Rev. SBPH v. 12 n. 2, Rio de Janeiro, dez., 2009. Disponível em: $<$ http://pepsic.bvsalud.org/pdf/rsbph/v12n2/v12n2a08.pdf>. Acesso em: 16 jan. 2017.

OSAVA, Ruth Hitomi. Assistência ao parto no Brasil: o lugar do não-médico. Tese (Doutorado em saúde pública). Departamento de Saúde Materno-Infantil da Faculdade de Saúde Pública da Universidade de São Paulo, São Paulo, 1997.

PARIENTE, Claudia. El parto es nuestro. Erradicar la maniobra de Kristeller - Una cuestión de gravedad para madres y bebés. Disponível em: <https://www.elpartoesnuestro.es/sites/default/files/public/blog/20130306Kristeller/nota_de_prensa_2013 _kristeller.pdf>. Acesso em: 15 jan. 2017.

RODRIGUES, Diego Pereira et al. A peregrinação no período reprodutivo: uma violência no campo obstétrico. Esc Anna Nery 2015;19(4):614-620. Disponível em: < http://www.scielo.br/pdf/ean/v19n4/1414-8145-ean19-04-0614.pdf>. Acesso em: 15 jan. 2017.

SCOTT, Joan. Gênero: uma Categoria Útil de Análise Histórica. Educação e Realidade, 1995.

PREVIATTI, Jaqueline Fátima; SOUZA, Kleyde Ventura de. Episiotomia: em foco a visão das mulheres. Revista Brasileira de Enfermagem, Brasília, v. 60, n. 2, p. 197-201, mar./abr. 2007. Disponível em: <http://www.scielo.br/pdf/reben/v60n2/a12v60n2.pdf>. Acesso em: 10 dez. 2015.

TAVIRA, Larissa V. O nascimento da clínica em Foucault - um poder-saber sobre a vida. (Em)Cena - Saúde Mental em Movimento. Palmas: Ceulp/Ulbra, 2014.

TEIXEIRA, Ananda Araújo et al. Distócia de ombro: relato de caso. Rev Med Minas Gerais 2012; 22 (Supl 5): S106-S108. Disponível em: <www.rmmg.org/exportar-pdf/679/v22s5a30.pdf>. Acesso em: 18 abr. 2017.

VENEZUELA. Ley Orgánica sobre el derecho de las mujeres a una vida libre de violência. Março, 2007. Disponível em: <http://venezuela.unfpa.org/sites/default/files/pub-pdf/Ley_mujer\%20\%281\%29_0.pdf>. Acesso em: 16 mar. 2016.

VENTURI G; GODINHO T. Mulheres brasileiras e gênero nos espaços público e privado. São Paulo: Sesc/Fundação Perseu Abramo; 2010. Disponível em: < http://www.apublica.org/wpcontent/uploads/2013/03/www.fpa_.org_br_sites_default_files_pesquisaintegra.pdf>. Acesso em: 02 nov. 2015. 
VENTURA, Miriam. Direitos reprodutivos no Brasil. Disponível em: <http://www.unfpa.org.br/Arquivos/direitos_reprodutivos3.pdf>. Acesso em: 20 jan. 2017.

ZORZAM, Bianca Alves de Oliveira. Informações e escolha no parto: perspectivas das mulheres usuárias do SUS e da Saúde Suplementar. 2013. Dissertação de Mestrado. Programa de Pós-Graduação em Saúde Pública. Universidade de São Paulo, São Paulo.

WOLFF, Leila Regina; WALDOW, Vera Regina. Violência consentida: mulheres em trabalho de parto e parto. Saúde Soc. São Paulo, v.17, n.3, p.138-151, 2008.

Trabalho enviado em 25 de abril de 2017.

Aceito em 23 de maio de 2017. 